\title{
Ultrastructural alterations in the midgut of Bacillus sphaericus-treated Culex pipiens (Diptera: Culicidae) larvae
}

\author{
Maha K. Tewfick ${ }^{*}$ and Belal A. Soliman
}

\begin{abstract}
The ultrastructure alterations were described in the midgut of Culex pipiens (Diptera: Culicidae) larvae following Bacillus sphaericus treatment. Two hours post-treatment, the epithelial layer began to have large amount of vacuoles. Explosion in the basement membrane took place $6 \mathrm{~h}$ post-treatment. Ten hours post-treatment, the bacterium began to invade the microvilli. At $14 \mathrm{~h}$ post-bacterial treatment, epithelial cells were destroyed, microvilli were damaged, and bacteria were present in lumen in large amount. The present study provided the evidence on the main aberrations induced in midgut larvae of $C$. pipiens as a result of ingesting $B$. sphaericus.
\end{abstract}

Keywords: Culex pipiens, Bacillus sphaericus, Midgut, Larva, TEM

\section{Background}

Culex pipiens Linnaeus complex mosquitoes transmit several diseases that affect humans and other animals (Michalski et al. 2010). These species oviposit in stagnant polluted water and populations are increasing and expanding due to creation of favorable habitats caused by urbanization (Bockarie et al. 2009), irrigation, and creation of the Aswan High Dam (Harb et al. 1993). Mosquito control strategy relies heavily on insecticides and particularly pyrethroids. However, widespread of pyrethroid resistance has hindered vector control implementation and sustainability (Shi et al. 2015).

Highly potent mosquitocidal strains of the microbial agent Bacillus sphaericus have been applied for the control of mosquito larvae around the world (Mulla et al. 2003). This organism has several advantages, including low environmental toxicity due to the high specificity of B. sphaericus toxins, high levels of efficacy and environmental persistence, and the ability to overcome resistance developed against conventional insecticides used worldwide (Nielsen-LeRoux et al. 2001). B. sphaericus crystal contains two major polypeptides, a $42-\mathrm{kDa}$ polypeptide and a 51-kDa polypeptide, which are designated BinA and BinB, respectively (Darboux et al. 2007). The mode of action of the toxin complex in susceptible

\footnotetext{
* Correspondence: kamalmaha2000@yahoo.com

Department of Zoology, Suez University, Suez, Egypt
}

mosquitoes involves highly specific binding to a receptor in the larval midgut (Silva-Filha et al. 1997). The two crystal components act synergistically; the BinB part is responsible for initial binding to the receptor, and the BinA component confers toxicity (Charles et al. 1997). A direct correlation exists between binding affinity and toxicity (Opota et al. 2008).

In mosquitoes, the first physical barrier met by ingested pathogens is the midgut epithelium; it is composed of a single layer of epithelial cells forming a microvillar surface on the luminal side (Hecker 1977).

The present study describes the ultrastructure alterations in the midgut of $C x$. pipiens larvae following $B$. sphaericus treatment.

\section{Materials and methods Mosquito rearing}

Immature stages of mosquito were collected from a drainage canal in Qualyobia Governorate, Egypt. Fourth instar larvae and emerging adults were identified according to Harbach (2012). Species other than $C x$. pipiens were discarded. Cx. pipiens larvae were reared in the laboratory under controlled conditions of temperature $\left(27 \pm 2{ }^{\circ} \mathrm{C}\right)$ and relative humidity $(70-$ $80 \%)$ and a $12 \mathrm{~L}: 12 \mathrm{D}$ photoperiod. Third instar larvae of the filial generation were used in the study. 

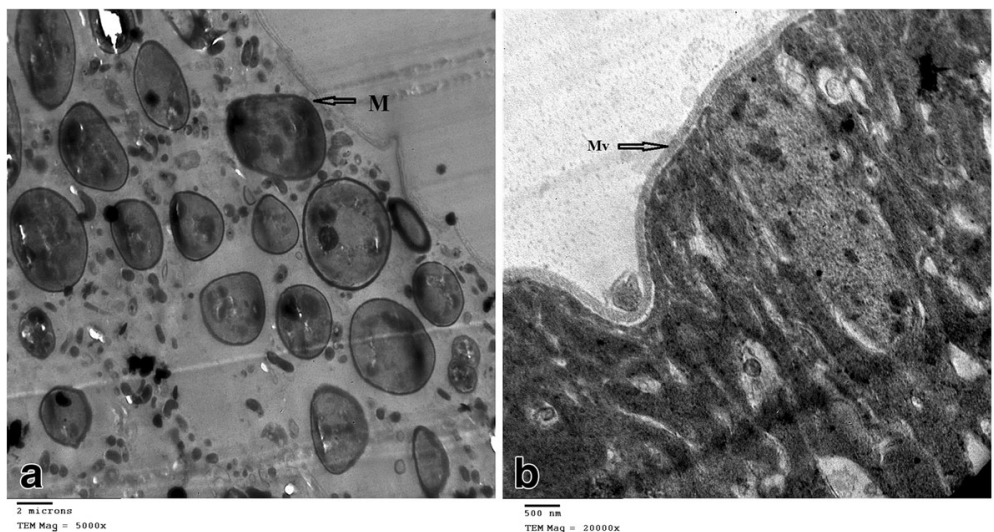

Fig. 1 Midgut ultrastructure of Culex pipiens third larval instar showing a M: mitochondria and $\mathbf{b}$ Mv: microvilli

\section{Bacterial strain and treatment}

Bacillus sphaericus strain 2362 was provided by Abbot Laboratories, North Chicago, IL, USA. The late third stage instar of $C x$. pipiens was treated with $\mathrm{LC}_{50}$ of $B$. sphaericus (0.07 ppm) (Soliman et al. 2000). Larvae were tested at the periods of $2,6,10$, and $14 \mathrm{~h}$ posttreatment. Individual midgut was dissected and prepared for TEM examination.

\section{Specimen tissue preparation for TEM}

Midgut of at least five larvae for each timing were fixed by immersion in 5\% glutaraldehyde in $0.1 \mathrm{M}$ sodium cacodylate buffer for $4 \mathrm{~h}$ at room temperature and then washed in $0.1 \mathrm{M}$ cacodylate buffer three times, $15 \mathrm{~min}$ for each. Specimens were secondarily fixed by immersion in $1 \%$ osmium tetroxide in $0.1 \mathrm{M}$ sodium cacodylate buffer for $2 \mathrm{~h}$ and then washed in $0.1 \mathrm{M}$ cacodylate buffer three times, $15 \mathrm{~min}$ for each. Fixed and washed specimens were dehydrated through a graded ethanol series (30, 50, 70, 90, 96, and 100\%) being kept at room temperature for 15 min during each step of the dehydration process. The absolute alcohol was replaced by propylene oxide or acetone via a stepwise series of ethanol: propylene oxide 2:1, $1: 1$, and $1: 2$ and then finally maintained in pure propylene oxide. Dehydrated specimens were embedded in epoxy resin.

Ultra-thin sections (50-80 nm thick) were cut, stained, and examined with a JEOL 1010 Transmission Electron Microscope (Martins et al. 2011).

\section{Results and discussion}

Examination of non-treated mosquito midgut larvae revealed that it was composed of a single-layered epithelium surrounded by a network of circular and longitudinal muscle bundles (Fig. 1a, b). The digestive cells had morphological characteristics of enterocyte cells and basolateral membrane. The free surface of enterocytes had a regular array of microvilli. Cells have spherical nuclei. Results of the present study were comparable to those found by Wassim et al. (2014) working on $C x$. pipiens midgut epithelium.

The morphological structures of B. sphaericus-treated $C x$. pipiens larval midgut showed modifications at the

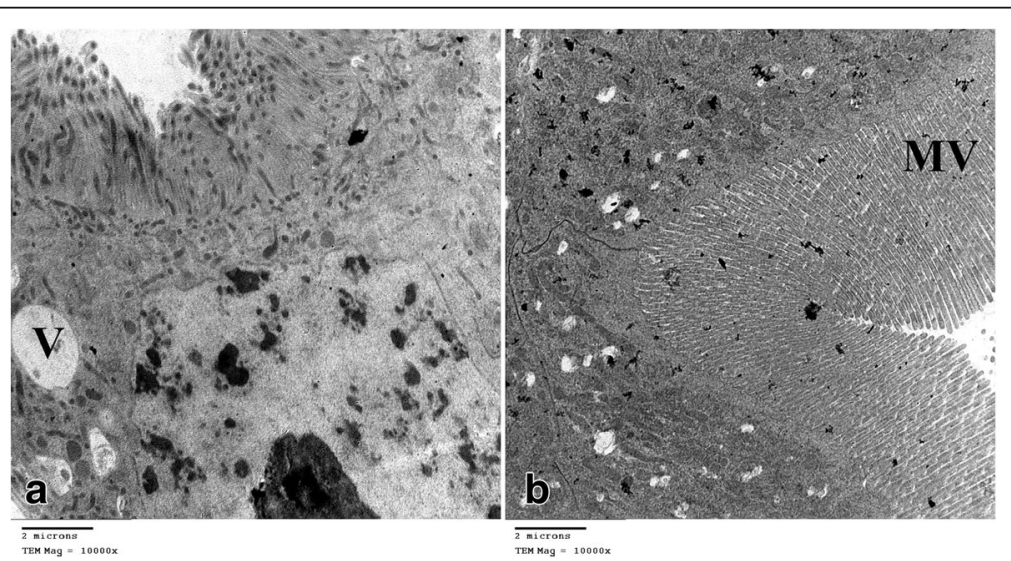

Fig. 2 Midgut ultrastructure of Culex pipiens third larval instar $2 \mathrm{~h}$ post Bacillus sphaericus treatment showing a V: vacuoles and b Mv: microvilli 


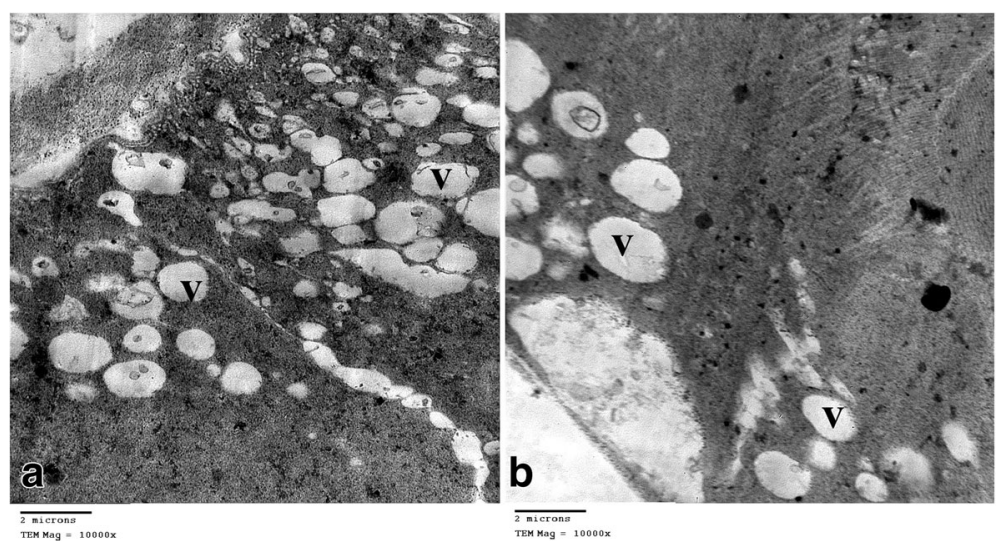

Fig. 3 Midgut ultrastructure of Bacillus sphaericus-treated Culex pipiens third larval instar $6 \mathrm{~h}$ post-treatment showing $\mathbf{a}$ and $\mathbf{b} \mathrm{V}$ : vacuoles

various timing following B. shaericus treatment. Two hours post-treatment, the epithelial layer began to have large amount of vacuoles (Fig. 2a). The microvilli were not affected (Fig. 2b). Examination revealed the presence of vacuoles in lumen cytoplasm. The early appearance of cytological disturbances, following bacterial treatment, could be correlated to the fast digestion of B. sphaericus cells in the anterior and central midgut (Labib and Dawoud 2003). Cytoplasmic vacuolization was reported to be one of the major cytotoxic responses of $C x$. mosquitoes to Bin intoxication (Silva-Filha et al. 1997). B. sphaericus bin-induced vacuolization was a transient phenomenon that affects autolysosomes and vacuolization was associated with induction of autophagy in intoxicated cells (Opota et al. 2008). Large vacuoles appeared early in the $C x$. pipiens mid-gut cells and rough endoplasmic reticula broke into small vesicles.

Six hours post-treatment, the amount of vacuoles increased in the epithelial layer (Fig. 3a, b). This timing showed the onset of abnormalities in the nucleus. Although microvilli were not affected, some positions lost their microvilli. Explosion in the basement membrane made it losing contact, a result that could be explained by the fact that $C x$. pipiens larval midgut was the primary target of the binary toxin (Bin) present in parasporal inclusions of $B$. sphaericus (Darboux et al. 2001).

Ten hours post-treatment, B. sphaericus spores were seen in the lumen (Fig. 4a). Microvilli were still intact (Fig. 4b). However, the bacterium began to invade the microvilli. At this time, the presence of bacteria was evident in the lumen. Bacteria began to enter the epithelial layer. The midgut epithelial cells of mosquito larvae intoxicated with Bin was reported to display several cytopathologies affecting the microvilli, the mitochondria, and the rough endoplasmic reticulum, but the most dramatic feature of Bin intoxication was the appearance of abnormal, electron-clear vacuoles indicating an important cellular stress (Silva-Filha et al. 1997). Bin toxin triggered apoptosis via an intrinsic or mitochondrial pathway in vivo, possibly contributing to larval death (Tangsongcharoen et al. 2015). However,
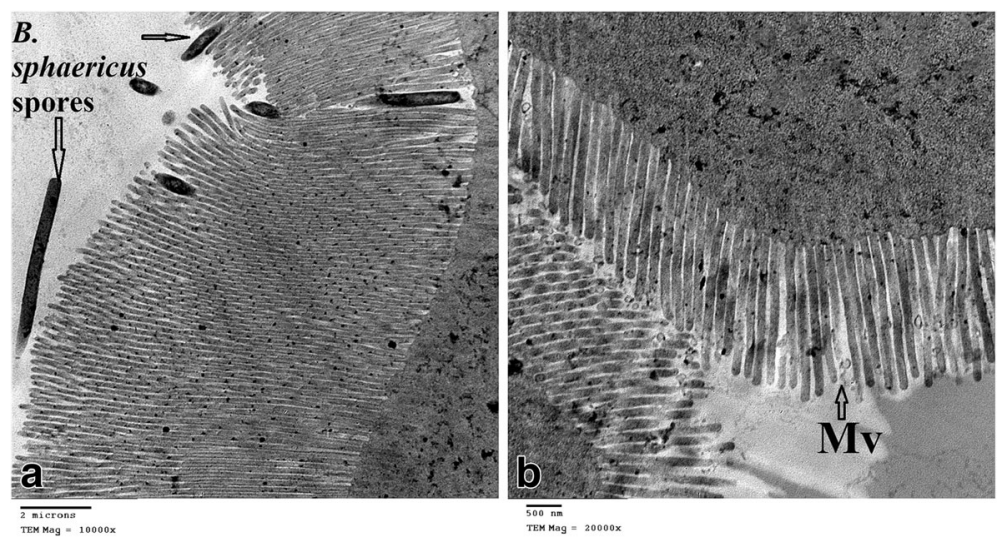

Fig. 4 Midgut ultrastructure of Bacillus sphaericus-treated Culex pipiens third larval instar $10 \mathrm{~h}$ post-treatment showing a B. sphaericus spores and b Mv: microvilli 


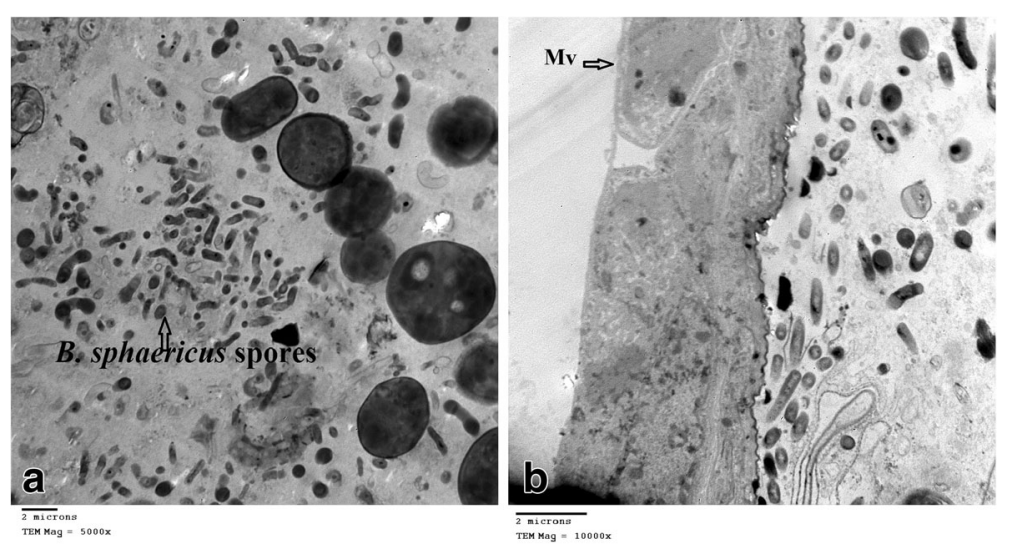

Fig. 5 Midgut ultrastructure of Bacillus sphaericus-treated Culex pipiens third larval instar 14 h post-treatment showing a B. sphaericus spores and b damaged microvilli

proliferation and differentiation of precursor stem cells could replace the destroyed midgut epithelial cells (Baton and Ranford-Cartwright 2007).

At $14 \mathrm{~h}$ post-bacterial treatment, bacteria were present in lumen in large amount (Fig. 5a), the result that agreed with that of Labib and Mohamad (2003) who found that the number of viable spores reached its maximum between 12 and $24 \mathrm{~h}$. Epithelial cells were destroyed. Microvilli were damaged as well (Fig. 5b). Binding to specific receptors on the apical microvilli membrane was considered as the initial step of delta-endotoxin action (Ravoahangimalala et al. 1993). Similarly, Cry4 produced by B. thuriengiensis israelensis were proved to bind to the microvilli of the epithelial cells of $C x$. pipiens posterior midgut and gastric caecae (Yamagiwa et al. 2001). On the contrary, microvilli of the midgut epithelial cells of Streptomyces griseus-treated Culex pipiens autogenicus larvae were unaltered, and there were no changes in the arrangement of cells in the tissues (Zizka et al. 1989).

Structural alterations in larval midgut following bacterial treatment are evident and enhance as the time proceeds. The present study provided a description of the main aberrations induced in midgut larvae of $C x$. pipiens as a result of $B$. sphaericus treatment.

\section{Conclusions}

The present study provided the evidence on the main aberrations induced in midgut larvae of $C x$. pipiens as a result of ingesting $B$. sphaericus.

\section{Abbreviations}

B.: Bacillus; Cx.: Culex

\section{Acknowledgements}

Preparation and examinations of ultra-sections were undergone in Regional Center for Mycology and Biotechnology (RCMB), Al-Azhar University, Egypt. The authors are grateful to Miss Dina Fathy for mosquito dissection.

\section{Funding}

The research had no sources of funding.

\section{Authors' contributions}

MKT contributed to the design of the work, mosquito collection and rearing, larval treatment with B. sphaericus, larval midgut dissection and examination of morphological structures of B. sphaericus-treated Cx. pipiens larval midgut, and preparing and revising of the manuscript. BAS supervised the work, examined morphological structures of $B$. sphaericus-treated $C$. pipiens larval midgut, and revised the manuscript. Both authors read and approved the final manuscript.

Ethics approval and consent to participate

Not applicable for that section.

\section{Consent for publication}

Not applicable for that section.

\section{Competing interests}

The authors declare that they have no competing interests.

\section{Publisher's Note}

Springer Nature remains neutral with regard to jurisdictional claims in published maps and institutional affiliations.

Received: 4 January 2018 Accepted: 21 February 2018

Published online: 29 March 2018

\section{References}

Baton LA, Ranford-Cartwright LC (2007) Morphological evidence for proliferative regeneration of the Anopheles stephensi midgut epithelium following Plasmodium falciparum Ookinete invasion. J Invertebr Pathol 96(3):244-254

Bockarie MJ, Pedersen EM, White GB, Michael E (2009) Role of vector control in the global program to eliminate lymphatic filariasis. Annu Rev Entomol 54:469-487

Charles JF, Silva-Filha MH, Nielsen-LeRoux C, Humphreys MJ, Berry C (1997) Binding of 51- and 42-kDa individual components from Bacillus sphaericus crystal toxin to mosquito larval midgut membranes from Culex and Anopheles sp. (Diptera: Culicidae). FEMS Microbiol Lett 156:153-159

Darboux I, Charles JF, Pauchet Y, Warot S, Pauron D (2007) Transposon-mediated resistance to Bacillus sphaericus in a field-evolved population of Culex pipiens (Diptera: Culicidae). Cell Microbiol 9(8):2022-2029

Darboux I, Nielsen-LeRoux C, Charles JF, Pauron D (2001) The receptor of Bacillus sphaericus binary toxin in Culex pipiens (Diptera: Culicidae) midgut: molecular cloning and expression. Insect Biochem Mol Biol 31(10):981-990

Harb M, Faris R, Gad AM, Hafez O, Ramzy R, Buck AA (1993) The resurgence of lymphatic filariasis in the Nile delta. Bull World Health Organ 71:49-54

Harbach RE (2012) Culex pipiens: species versus species complex-taxonomic history and perspective. J Am Mosq Control Assoc 28(4Suppl):10-23 
Hecker H (1977) Structure and function of midgut epithelial cells in Culicidae mosquitoes (Insecta, Diptera). Cell Tissue Res 184:321-341

Labib IM, Dawoud HA (2003) Cytopathological action in mosquito larvae fed with Bacillus sphaericus (strain faiyoum) spore/crystal complex. J Egypt Soc Parasitol 33(2):517-530

Labib IM, Mohamad AA (2003) Laboratory evaluation of Bacillus sphaericus recycling in mosquito larvae. J Egypt Soc Parasitol 33(2):425-436

Martins GF, Serrão JE, Ramalho-Ortigão JM, Pimenta PF (2011) Histochemical and ultrastructural studies of the mosquito Aedes aegypti fat body: effects of aging and diet type. Microsc Res Tech 74(11):1032-1039

Michalski ML, Erickson SM, Bartholomay LC, Christensen BM (2010) Midqut barrier imparts selective resistance to filarial worm infection in Culex pipiens pipiens. PLoS Negl Trop Dis 4(11):e875

Mulla MS, Thavara U, Tawatsin A, Chomposri J, Su T (2003) Emergence of resistance and resistance management in field populations of tropical Culex quinquefasciatus to the microbial control agent Bacillus sphaericus. J Am Mosq Control Assoc 19(1):39-46

Nielsen-LeRoux C, Rao DR, Murphy JR, Carron A, Mani TR, Hamon S, Mulla MS (2001) Various levels of cross-resistance to Bacillus sphaericus strains in Culex pipiens (Diptera: Culicidae) colonies resistant to B. sphaericus strain 2362. Appl Environ Microbiol 67(11):5049-5054

Opota O, Charles JF, Warot S, Pauron D, Darboux I (2008) Identification and characterization of the receptor for the Bacillus sphaericus binary toxin in the malaria vector mosquito, Anopheles gambiae. Comp Biochem Physiol B Biochem Mol Biol 149(3):419-427

Ravoahangimalala O, Charles JF, Schoeller-Raccaud J (1993) Immunological localization of Bacillus thuringiensis serovar israelensis toxins in midgut cells of intoxicated Anopheles gambiae larvae (Diptera: Culicidae). Res Microbiol 144(4):271-278

Shi L, Hu H, Ma K, Zhou D, Yu J, Zhong D, Fang F, Chang X, Hu S, Zou F, Wang W, Sun Y, Shen B, Zhang D, Ma L, Zhou G, Yan G, Zhu C (2015) Development of resistance to pyrethroid in Culex pipiens pallens population under different insecticide selection pressures. PLoS Negl Trop Dis 9(8):e0003928

Silva-Filha MH, Nielsen-LeRoux C, Charles JF (1997) Binding kinetics of Bacillus sphaericus binary toxin to midgut brush border membranes of Anopheles and Culex spp. mosquito larvae. Eur J Biochem 247:754-761

Soliman BA, Tewfick MK, Hafez GA (2000) Potential for Culex pipiens to develop resistance against Bacillus sphaericus toxins. J Egypt Soc Parasitol 30(3):839-849

Tangsongcharoen C, Chomanee N, Promdonkoy B, Boonserm P (2015) Lysinibacillus sphaericus binary toxin induces apoptosis in susceptible Culex quinquefasciatus larvae. J Invertebr Pathol 128:57-63

Wassim NM, Soliman BA, Hussein MI, Metwaly HG (2014) Isolation of stem cells from the mid gut epithelium of Culex pipiens mosquitoes (Diptera: Culicidae). J Egypt Soc Parasitol 44(1):13-20

Yamagiwa M, Kamauchi S, Okegawa T, Esaki M, Otake K, Amachi T, Komano T, Sakai H (2001) Binding properties of Bacillus thuringiensis Cry4A toxin to the apical microvilli of larval midgut of Culex pipiens. Biosci Biotechnol Biochem 65(11):2419-2427

Zizka Z, Weiser J, Blumauerova M, Jizba J (1989) Ultra structural effects of macrotetrolides of Streptomyces griseus LKS-1 in tissues of Culex pipiens larvae. Cytobios 58(233):85-91

\section{Submit your manuscript to a SpringerOpen ${ }^{\circ}$ journal and benefit from:}

- Convenient online submission

- Rigorous peer review

- Open access: articles freely available online

- High visibility within the field

- Retaining the copyright to your article

Submit your next manuscript at $\gg$ springeropen.com 